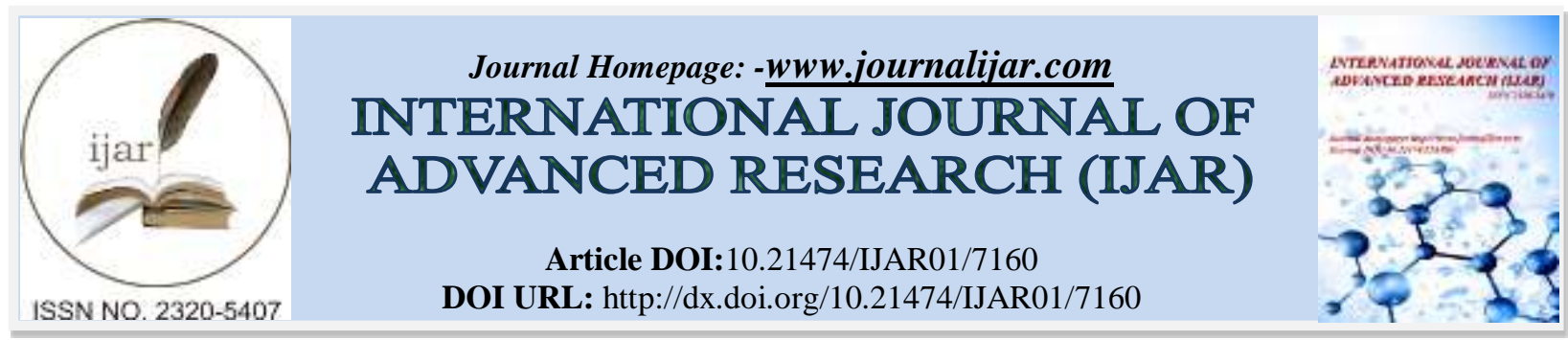

RESEARCH ARTICLE

\title{
BIOCHEMICAL STUDIES ON AMELIORATIVE EFFECT OF PROBIOTIC ON INDUCED OBESITY IN RAT.
}

\author{
Mohamed Ahmed Kandeil ${ }^{1}$, Ghada Mohamed Safwat ${ }^{1}$, Mahmoud Mohamed Arafa ${ }^{2}$ and Doaa Ahmed \\ Mansour'. \\ 1. Biochemistry Department, Faculty of Veterinary Medicine, Beni-Suef University,Beni-Suef, Egypt. \\ 2. Biochemistry Department, Animal Health Research Institute, Dokki, Giza, Egypyt.
}

\section{Manuscript Info \\ Manuscript History \\ Received: 21 March 2018 \\ Final Accepted: 23 April 2018 \\ Published: May 2018}

Keywords:-

Palm oil, sucrose, obesity, probiotics,

liver, Leptin.

\begin{abstract}
Obesity is a significant cause of morbidity and mortality worldwide. Obesity was induced in our experiment by consumption of diet containing $15 \%$ palm oil and by adding of sucrose $(20 \%)$ to the drinking water for a period of 16 weeks. Probiotics have several health benefits so we used PROBAC Plus $\left(20\right.$ million $\mathrm{mo}_{\mathrm{s}} / \mathrm{g}$. $)$ to evaluate its ameliorative effect on biochemical changes associated with obesity. It composed of Lactobacillus Acidophilus, Lactobacillus Planterum, Lactobacillus Bervis, Bifidobacteriais and Saccharomyces Cerevisiae. 80 male albino rats were divided into control group $(\mathrm{Cr})$, High fat diet \&sucrose group (HFDS), probiotic group (Pro.), High fat diet \& sucrose + probiotic group (HFDS+ Pro.) and High fat diet\& sucrose then probiotic group (HFDS then Pro.). Consumption of palm oil and sucrose for 16 weeks leads to a significant increase in body weight and abdominal fat mass compared to normal rats. In addition, there was a significant increase in the level of serum triacylglycerol, total cholesterol, LDL-C, liver enzymes and leptin hormone. Malondialdehyde (MDA) and TNF- $\alpha$ concentration of liver homogenate were also significantly increased. It was also observed a significant reduction in serum level of HDL-C. The concentration of SOD and reduced glutathione (GSH) in liver homogenate were reduced. Use of probiotic as proflactive or as treatment return serum lipid profile, liver function enzymes, antioxidant parameters, TNF- $\alpha$ and leptin hormone towards its normal value. These results confirm the beneficial role of probiotic for treatment of obesity.
\end{abstract}

Copy Right, IJAR, 2018,. All rights reserved.

\section{Introduction:-}

Obesity is a metabolic disorder affecting healthy globally (Sabzghabaee et al., 2014) and a significant cause of morbidity and mortality worldwide (Austin and Marks, 2009). Obesity is defined as abnormal or excessive fat accumulation that may impair health (Wąsowski et al., 2013). It is associated with an increased risk of numerous chronic diseases, from diabetes and cancers to many digestive diseases and to disability and death. In addition, the obesity epidemic represents a heavy burden on the economy with its massive healthcare costs (Maggi et al., 2015). 
Body weight is tightly regulated by complex homeostatic mechanisms. The World Health Organization defines obesity as a body mass index (BMI) > 30 and defines overweight as with a BMI of 25 (Sikaris, 2004).

Palm oil is a type of edible oil obtained from the mesocarp of the fruits of the tropical plant Elaeis guineensis. Palm oil represents $30 \%$ of the worlds vegetable oil production, and its consumption has increased rapidly in the past several decades, particularly in emerging economies such as India and China (Walter, 2009).

Many high-fat diets used in laboratory animal research contain more saturated fat such as lard, beef tallow, or coconut oil and are quite capable of inducing metabolic disorders such as obesity, insulin resistance or glucose intolerance in susceptible strains. In our study we used palm oil.

palm oil contains a high amount of saturated fat (40-50\% of total fat) with the majority being in the form of palmitic acid (16:0) (Zhao et al., 2005). Consequently, high intakes of saturated fat from palm oil induce a larger increase in plasma concentrations of total cholesterol and low-density lipoproteins. Many studies provide a concise and comprehensive update on the functional role of palm oil and palmitic acid in the development of obesity, type 2 diabetes mellitus, cardiovascular diseases and cancer (Mancini et al., 2015a).

Consumption of sucrose aggravates the metabolic consequences of high fat enriched diet and induces dyslipidemia. (Ngueguim et al., 2016 and Braud et al., 2017) used 10\% sucrose in drinking water for induction of obesity.

Gut microbes induce a wide variety of host responses within the intestinal mucosa and thereby control the gut's barrier and endocrine functions. Gut microbes also influence the metabolism of cells in tissues outside of the intestines (in the liver and adipose tissue) and thereby modulate lipid and glucose homeostasis, as well as systemic inflammation, in the host. Number of studies suggested that specific phyla, classes or species of bacteria, or bacterial metabolic activities could be beneficial or for treatment of obesity and its complications (Delzenne et al., 2011).

Probiotics are live microbes that, when administered in adequate amounts, have been shown to confer health benefits to the host. Over the years, probiotics have been a part of the human diet in the form of different fermented foods consumed around the world. Their influence on different physiologic functions in the host is documented (Arora et al., 2013a).

Probiotics and prebiotics are of interest because alteration in the composition of gut microbiota affect food intake and appetite, body weight and metabolic functions through modulation of the gut bacterial community (Sanchez et al., 2015).

Many researchers reported the beneficial effect of different single strain probiotic on obesity as (Minami et al., 2015 and Wu et al., 2015) who reported the anti-obesity effect of Bifidobacterium breve B-3 and Lactobacillus plantarum respectively in the high-fat diet-induced obesity in mice. (Yoo et al., 2013) showed that multiple-strain probiotics were more effective than each of the constituent single-strain probiotics because of the synergistic effects on host health.

In the present study, we investigated the anti-obesity effect of five potential probiotic strains (Lactobacillus Acidophilus, Lactobacillus Planterum, Lactobacillus Bervis, Bifidobacteriais and Saccharomyces Cerevisiae) on high fat diet (15\% palm oil) \& sucrose (20\% in drinking water) induced obesity in rats.

\section{Materials and Methods:-}

\section{Diets and drinking water:-}

The standard normal chow diet:-

The standard normal chow diet purchased from El Fagr Factory for feed manufacture, Cairo, Egypt. The standard normal chow diet consists of soybean meal (44\%), wheat corn, soybean oil, Gelatin (60\%), di-calcium phosphate, sodium chloride, choline chloride, methionine, Lysine and vitamins and trace elements mixture. The chemical analysis of the standard normal rat chow diet are not less than $21 \%$ crude protein, not less than $6.2 \%$ fat , not more than $3.5 \%$ crude fibers, $6 \%$ ach, $7.8 \%$ humidity and $55.5 \%$ carbohydrates and the metabolic energy of this diet is $3100 \mathrm{kcal} / \mathrm{kg}$. 


\section{The high fat diet contains palm oil and sucrose:-}

Palm oil purchased from Ajwa for food industries company, Cairo, Egypt. It was added to the ration as $15 \%$ of the ration weight (Motshakeri et al., 2015). The chemical analysis of the high fat diet are $21.5 \%$ crude protein, $15 \%$ fat, $2.35 \%$ crude fibers, $6 \%$ ach, $7.8 \%$ humidity and $47.35 \%$ carbohydrates and the metabolic energy of this diet is 4200 $\mathrm{kcal} / \mathrm{kg}$.

\section{Drinking water containing Sucrose:-}

Pure sucrose (O- $\alpha$-D-glucopyranosyl- $(1 \rightarrow 2)-\beta$-D-fructofuranoside) which manufactured by ISO-CHEM pharmaceutical(fine) chemicals Company, Egypt, was added to normal tap water day after day with percentage of 20\% according to (Motshakeri et al., 2015; Ngueguim et al., 2016).

\section{Probiotics mixture:-}

In our experiment, PROBAC Plus (20 million $\mathrm{mo}_{\mathrm{s}} / \mathrm{gm}$ ) was used which composed of Lactobacillus Acidophilus, Lactobacillus Planterum, Lactobacillus Bervis, Bifidobacteriais and Saccharomyces Cerevisiae. It was manufactured by VIGORA Company, Egypt. It was administrated orally by stomach tube to each rat in a dose of $0.571 \mathrm{~g}\left(\mathbf{1} \times 10^{8}\right.$ CFU) once daily suspended in $1.5 \mathrm{ml}$ of saline according to (An et al., 2011; Wang et al., 2015).

\section{Experimental animals:-}

The present study was carried out on 80 male Albino rats of 140-160 g body weight range. Rats were purchased from National Research Centre, Dokki, Giza, Egypt. Rats were kept under observation for one week before the onset of experiment to be acclimatized. Rats were housed in metallic cages at a room temperature of $22 \pm 1^{\circ} \mathrm{C}$ under a 12 -h light- dark natural cycle in the lab of biochemistry in Faculty of Veterinary Medicine, Beni-Suef University. All experimental procedures were conducted in agreement with the guide for the care and use of laboratory animals and in accordance with the local Animal Care and Use Committee.

\section{Experimental Design:-}

Our experiment continued for 16 weeks and rats were divided equally into five groups as the following:

Control group $(\mathrm{Cr})$ : this group of rats maintained on normal taps drinking water and standard normal rat chow diet, along the period of experiment (16 weeks).

High fat diet \& sucrose group (HFDS): this group of rats maintained on special tap drinking water (20\% sucrose add to water) and high fat diet (15\% palm oil add to normal rat chow diet) along the period of experiment (16 weeks).

Probiotic group (Pro.): this group of rats maintained on normal taps drinking water and standard normal rat chow diet, with daily oral administration of PROBAC Plus $(0.571 \mathrm{~g} / \mathrm{rat})$ by using of stomach tube for all period of experiment (16 weeks).

High fat diet \& sucrose + probiotic group (HFDS+ Pro.): this group of rats maintained on special tap drinking water (20\% sucrose add to water) and high fat diet (15\% palm oil add to normal rat chow diet), with oral administration of $\operatorname{PROBAC}_{\text {Plus }}(0.571 \mathrm{~g} / \mathrm{rat})$ daily by using of stomach tube for all period of experiment (16 weeks).

High fat diet \& sucrose then probiotic group (HFDS then Pro.):this group of rats maintained on special tap drinking water(20\% sucrose add to water) and high fat diet (15\% palm oil add to normal rat chow diet) along the period of experiment (16 weeks) and treated with PROBAC Plus $(0.571 \mathrm{~g} / \mathrm{rat})$ from the beginning of $8^{\text {th }}$ week till the end of experiment according to (Park et al., 2013). During the study, animals allowed the diets and water in free manner. Body weight of rats was recorded weekly.

\section{Blood analysis:-}

At the end of experiment and after $12 \mathrm{hrs}$ rats were sacrificed under mild diethyl ether anesthesia. Blood samples were collected from jugular vein. Serum was separated by centrifuge with Heraeus centrifuge at $3500 \mathrm{rpm}$ for 15 minutes and divided into several aliquots which stored at $-20^{\circ} \mathrm{C}$ until biochemical analysis. Abdominal incisions were done for separation of liver and abdominal fat mass for weighting. $0.5 \mathrm{~g}$. of each liver tissue was homogenized with $5 \mathrm{ml}$ of $0.9 \%$ sterilized $\mathrm{NaCL}(10 \% \mathrm{w} / \mathrm{v})$ using teflon homogenizer (Glas-Col, Terre Haute, USA),then centrifuged at $3500 \mathrm{rpm}$ for 15 minutes. The supernatants were removed and stored at $-20^{\circ} \mathrm{C}$ for quantitative 
determination of reduced glutathione (GSH), malondialdehyde (MDA), superoxide dismutase (SOD) and Cytokines $(\mathrm{TNF} \alpha)$.

\section{Biochemical analysis:-}

Serum total cholesterol level was determined by using of colorimetric method (CHOD-PAP) according to (Richmond, 1973). Serum triacylglycerol and HDL $-\mathrm{C}$ levels were determined by colorimetric method according to (Fossati and Prencipe, 1982) and (Burstein et al., 1970) respectively and by using of the commercial diagnostic laboratory kits (Diamond Company, Cairo, Egypt). Serum concentration of LDL-C and VLDL- C were calculated according to the formula of (Friedewald et al., 1972).

The serum activities of ALT and AST were determined colorimetric ally according to (Reitman and Frankel, 1957) and by using Diamond company diagnostic laboratory commercial kits.

The serum activities of ALP and GGT were determined by kinetic method according to (Szasz, 1969) and (Bray, 1974) and by using of Diamond company diagnostic laboratory commercial kits.

Serum leptin level was analyzed by Radio Immune -Assay (RIA) method using RIA kits, Amersham international Ltd Amersham United Kingdom.

Reduced glutathione (GSH), super oxide dismutase (SOD) and malondialdehyde (MDA) levels of liver homogenate were determined by colorimetric method according to (Beutler et al., 1963), (Nishikimi et al., 1972) and (Satoh, 1978) respectively and by using of commercial diagnostic laboratory kit (Biodignostic company, Cairo, Egypt). TNF- $\alpha$ level of liver homogenate was determined by ELISA method according to (Kjems et al., 1993) by using of Rat TNF-alpha ELISA Kit, pink-ONE (Koma Biotech Inc., Korea).

\section{Statistical analysis:-}

Statistical analysis was carried out using Graph Pad Instate software (version 3. ISS-Rome, Italy) (Graph Pad Soft Ware. 2014).Unless differently specified, groups of data were compared with un-paired t-test and one-way analysis of variance (ANOVA) followed by Tukey-kramer (TK) multiple comparisons post-test. Values of $\mathrm{P}<0.001$ were regarded as significant. The data, as clearly indicated are reported in tables and figures as mean \pm standard error (S.E).

\section{Results:-}

Table 1:-Effect Of High Fat Diet \& Sucrose (Hfds) And Probiotic On Body Weight And Abdominal Fat Mass In Different Rat Groups After 16 Weeks.

\begin{tabular}{|l|l|l|l|l|l|}
\hline $\begin{array}{l}\text { Groups of rats } \\
\text { Parameters }\end{array}$ & Hrobs group & probiotic group & $\begin{array}{l}\text { HFDS }+ \text { probiotic } \\
\text { group }\end{array}$ & $\begin{array}{l}\text { HFDS } \\
\text { then } \\
\text { probiotic group }\end{array}$ \\
\hline Mean of body weight (g.) & $290 \pm 6.01$ & $331.11 \pm 7.72^{\mathrm{a}}$ & $287.22 \pm 4.26^{\mathrm{b}}$ & $318.88 \pm 7.89^{\text {he }}$ & $310.55 \pm 8.44$ \\
\hline $\begin{array}{l}\text { Mean of abdominal fat } \\
\text { mass (g.) }\end{array}$ & $5.8 \pm 0.44$ & $12.1 \pm 0.70^{\mathrm{a}}$ & $5.12 \pm 0.53^{\mathrm{b}}$ & $6.9 \pm 0.78^{\mathrm{b}}$ & $6.24 \pm 0.36^{\mathrm{b}}$ \\
\hline
\end{tabular}

-Values are statistically analyzed by one way ANOVA test followed by Tukey-Kramer posttest and reported as mean \pm SE.

-Number of animals in each group is 16.

${ }^{\mathrm{a}} \mathrm{P}<0.001$ vs $\mathrm{Cr}$ group \& ${ }^{\mathrm{h}} \mathrm{P}<0.05$ vs $\mathrm{Cr}$ group.

${ }^{\mathrm{b}} \mathrm{P}<0.001$ vs HFDS group.

${ }^{\mathrm{e}} \mathrm{P}<0.05$ vs probiotic group.

Results in (table1) showed a significant increase in body weight (g.) of rats in the HFDS group after 16 weeks of consumption of high fat diet containing $15 \%$ palm oil and by adding of sucrose $(20 \%)$ to the drinking water in comparison to control group and also to the probiotic group. Also body weight (g.) of rats was increased in the HFDS + probiotic group in comparison to control group and probiotic group. Using of probiotic mixture with HFDS from the beginning of the experiment (HFDS + probiotic group) or from the beginning of $8^{\text {th }}$ week (HFDS then probiotic group) led to non-significant decrease in body weight of rats in comparison to HFDS. Results in the same 
table revealed that abdominal fat mass (g.) was significantly increased in HFDS group in comparison to control group. Administration of probiotic mixture led to a significant decrease in abdominal fat mass (g.) in (probiotic group), (HFDS + probiotic group) and (HFDS then probiotic group) in comparison to HFDS group.

Table 2:-Effect Of High Fat \& Sucrose (Hfds) And Probiotic On Serum Lipid Profile In Different Rat Groups At The End Of The Experiment (16 Weeks).

\begin{tabular}{|c|c|c|c|c|c|}
\hline $\begin{array}{l}\text { Groups of rats } \\
\text { Parameters }\end{array}$ & Cr group & HFDS group & $\begin{array}{l}\text { probiotic } \\
\text { group }\end{array}$ & $\begin{array}{l}\text { HFDS }+ \\
\text { probiotic } \\
\text { group }\end{array}$ & $\begin{array}{l}\text { HFDS then probiotic } \\
\text { group }\end{array}$ \\
\hline Serum TC (mg/dl) & $180.8 \pm 2.1$ & $398 \pm 7.6^{\mathrm{a}}$ & $169.6 \pm 2.9^{b}$ & $228 \pm 3.5^{\mathrm{ab}}$ & $244.8 \pm 3.5^{\mathrm{ab}}$ \\
\hline Serum TAG (mg/dl) & $129 \pm 3.6$ & $291.2 \pm 2.9^{\mathrm{a}}$ & $177 \pm 2.1^{\mathrm{b}}$ & $175 \pm 3.9^{\mathrm{abc}}$ & $196.2 \pm 2.8^{\mathrm{abc}}$ \\
\hline $\begin{array}{l}\begin{array}{l}\text { Serum } \\
(\mathrm{mg} / \mathrm{dl})\end{array} \\
\text { HDL-C }\end{array}$ & $69.4 \pm 0.4$ & $50 \pm 1.8^{\mathrm{a}}$ & $71.6 \pm 1.7^{b}$ & $63.6 \pm 1.3^{\text {be }}$ & $56.6 \pm 1.9^{\text {adc }}$ \\
\hline $\begin{array}{l}\text { Serum } \\
(\mathrm{mg} / \mathrm{dl})\end{array} \quad$ LDL-C & $86.6 \pm 2.3$ & $290.56 \pm 7.7^{\mathrm{a}}$ & $74.6 \pm 2.9^{b}$ & $131.4 \pm 4.5^{\mathrm{abc}}$ & $148.88 \pm 4.5^{\mathrm{abc}}$ \\
\hline $\begin{array}{l}\text { Serum } \\
(\mathrm{mg} / \mathrm{dl})\end{array} \quad$ VLDL-C & $25.8 \pm 0.7$ & $54.24 \pm 4.2^{\mathrm{a}}$ & $23.4 \pm 0.4^{b}$ & $33 \pm 2.5^{\text {be }}$ & $39.32 \pm 0.6^{\mathrm{fgc}}$ \\
\hline
\end{tabular}

-Values are statistically analyzed by one way ANOVA test followed by Tukey-Kramer posttest and reported as mean \pm SE.

-Number of animals in each group is 16.

${ }^{\mathrm{a}} \mathrm{P}<0.001$ vs $\mathrm{Cr}$ group $\&{ }^{\mathrm{F}} \mathrm{P}<0.01$ vs $\mathrm{Cr}$ group.

${ }^{\mathrm{b}} \mathrm{P}<0.001$ vs HFDS group $\&{ }^{\mathrm{d}} \mathrm{P}<0.05$ vs HFDS group $\&^{\mathrm{g}} \mathrm{P}<0.01$ vs HFDS group.

${ }^{\mathrm{c}} \mathrm{P}<0.001$ vs probiotic group $\&{ }^{\mathrm{e}} \mathrm{P}<0.05$ vs probiotic group.

Results in (table 2) showed an extremely significant increase in serum total cholesterol, triacylglycerol, LDL-C and VLDL-C concentrations in the HFDS group of rats in comparison to control group, while the serum level of HDL-C was significantly decreased. Administration of probiotic led to extremely significant decrease in the serum concentration level of total cholesterol, triacylglycerol, LDL-C and VLDL-C in the (probiotic group), (HFDS + probiotic group) and (HFDS then probiotic group) in comparison to HFDS group, while serum HDL-C level was significantly increased in comparison to HFDS group.

Table 3:-Effect Of High Fat \& Sucrose (Hfds) And Probiotic On Liver Function Enzymes In Different Rat Groups At The End Of The Experiment (16 Weeks).

\begin{tabular}{|c|c|c|c|c|c|}
\hline $\begin{array}{l}\text { Groups of rats } \\
\text { parameters }\end{array}$ & Cr group & HFDS group & probiotic group & $\begin{array}{l}\text { HFDS }+ \\
\text { probiotic group }\end{array}$ & $\begin{array}{l}\text { HFDS then } \\
\text { probiotic group }\end{array}$ \\
\hline $\begin{array}{l}\text { Serum } \\
(\text { IU/L) }\end{array}$ & $24 \pm 1.1$ & $52 \pm 1.1^{\mathrm{a}}$ & $20.2 \pm 0.7^{\mathrm{hb}}$ & $22.6 \pm 0.4^{b}$ & $30 \pm 0.8^{a b c}$ \\
\hline $\begin{array}{l}\text { Serum } \\
(\text { IU/L) }\end{array} \quad$ AST & $24.4 \pm 1.6$ & $59 \pm 1.6^{\mathrm{a}}$ & $22.6 \pm 0.8^{b}$ & $27 \pm 0.9^{b}$ & $34.2 \pm 1.5^{\mathrm{abc}}$ \\
\hline $\begin{array}{l}\text { Serum } \\
(\mathrm{mg} / \mathrm{dl})\end{array} \quad$ ALP & $43.2 \pm 0.7$ & $101.8 \pm 2.7^{\mathrm{a}}$ & $44 \pm 0.7^{b}$ & $47.8 \pm 1.0^{b}$ & $68.4 \pm 1.3^{\mathrm{abc}}$ \\
\hline $\begin{array}{l}\text { Serum } \\
(\mathrm{mg} / \mathrm{dl})\end{array} \quad$ GGT & $13.6 \pm 0.5$ & $34 \pm 1.6^{\mathrm{a}}$ & $14 \pm 0.5^{b}$ & $16.6 \pm 0.5^{b}$ & $21.2 \pm 0.7^{\mathrm{abc}}$ \\
\hline
\end{tabular}

-Values are statistically analyzed by one way ANOVA test followed by Tukey-Kramer posttest and reported as mean \pm SE.

-Number of animals in each group is 16.

${ }^{\mathrm{a}} \mathrm{P}<0.001$ vs $\mathrm{Cr}$ group $\&{ }^{\mathrm{h}} \mathrm{P}<0.05$ vs $\mathrm{Cr}$ group.

${ }^{\mathrm{b}} \mathrm{P}<0.001$ vs HFDS group

${ }^{\mathrm{c}} \mathrm{P}<0.001$ vs probiotic group 
Results in (table 3) revealed an extremely significant increase in serum levels of liver function enzymes (ALT, AST, ALP, GGT) of HFSD group as compared with control group of rats. Probiotic mixture administration represented by (probiotic group), (HFDS + probiotic group) and (HFDS then probiotic group) led to extremely significant decrease in the previous parameters as to HFSD group.

Table 4:-Effect Of High Fat \& Sucrose (Hfds) And Probiotic On Reduced Glutathione (Gsh), Super Oxide Dismutase (Sod) And Malondialdehyde (Mda) Of Liver Homogenate In Different Rat Groups At The End Of The Experiment (16 Weeks).

\begin{tabular}{|l|l|l|l|l|l|}
\hline Groups of rats & Cr group & HFDS group & $\begin{array}{l}\text { probiotic } \\
\text { group }\end{array}$ & $\begin{array}{l}\text { HFDS } \\
\text { probiotic } \\
\text { group }\end{array}$ & $\begin{array}{l}\text { HFDS } \\
\text { probiotic group }\end{array}$ \\
\hline $\begin{array}{l}\text { liver GSH } \\
\text { ( mg/g tissue) }\end{array}$ & $23.8 \pm 0.58$ & $11.2 \pm 0.4^{\mathrm{a}}$ & $23.2 \pm 0.4^{\mathrm{b}}$ & $25.6 \pm 0.5^{\text {be }}$ & $20 \pm 0.7^{\text {abi }}$ \\
\hline $\begin{array}{l}\text { liver SOD } \\
\text { (U/g tissue ) }\end{array}$ & $2.5 \pm 0.07$ & $0.85 \pm 0.04^{\mathrm{a}}$ & $2.26 \pm 0.051^{\mathrm{b}}$ & $2.26 \pm 0.12^{\mathrm{b}}$ & $1.58 \pm 0.13^{\mathrm{abc}}$ \\
\hline $\begin{array}{l}\text { liver MDA } \\
\text { (nmol/gm tissue) }\end{array}$ & $32.8 \pm 0.9$ & $90 \pm 3.0^{\mathrm{a}}$ & $37.2 \pm 1.0^{\mathrm{b}}$ & $30.2 \pm 0.5^{\mathrm{be}}$ & $47.2 \pm 1.16^{\mathrm{abi}}$ \\
\hline
\end{tabular}

-Values are statistically analyzed by one way ANOVA test followed by Tukey-Kramer posttest and reported as mean \pm SE.

-Number of animals in each group is 16.

${ }^{\mathrm{a}} \mathrm{P}<0.001$ vs $\mathrm{Cr}$ group.

${ }^{\mathrm{b}} \mathrm{P}<0.001$ vs HFDS group.

${ }^{\mathrm{c}} \mathrm{P}<0.001$ vs probiotic group $\&^{\mathrm{e}} \mathrm{P}<0.05$ vs probiotic group $\&^{\mathrm{i}} \mathrm{P}<0.01$ vs probiotic group

Results in (table4) revealed an extremely significant decrease in GSH, SOD and increase in MDA concentrations in liver tissue homogenate of HFSD group as compared to control group. There were no significant changes between probiotic group and control group. Administration of probiotic led to extremely significant increase in GSH, SOD and decrease in MDA concentrations of liver tissue homogenate when compared to HFSD group.

Table 5:-Effect Of High Fat \& Sucrose (Hfds) And Probiotic On Serum Leptin Level And Liver Homogenate Tnf-A In Different Rat Groups At The End Of The Experiment (16 Weeks).

\begin{tabular}{|l|l|l|l|l|l|}
\hline $\begin{array}{l}\text { Groups of rats } \\
\text { parameters }\end{array}$ & Cr group & $\begin{array}{l}\text { HFDS } \\
\text { group }\end{array}$ & probiotic group & $\begin{array}{l}\text { HFDS with probiotic } \\
\text { group }\end{array}$ & $\begin{array}{l}\text { HFDS then } \\
\text { probiotic } \\
\text { group }\end{array}$ \\
\hline Serum leptin (ug/l ) & $6.0 \pm 0.3$ & $15.0 \pm 1.7^{\mathrm{a}}$ & $3.4 \pm 0.4^{\mathrm{b}}$ & $11.2 \pm 1.105^{\mathrm{k}}$ & $13.5 \pm 0.3^{\mathrm{f}}$ \\
\hline $\begin{array}{l}\text { liver TNF- } \boldsymbol{\alpha}(\mathbf{m g} / \mathbf{m l} \\
\text { ) }\end{array}$ & $8.6 \pm 1.17$ & $15.5 \pm 1.8^{\mathrm{f}}$ & $7.5 \pm 1.041^{\mathrm{g}}$ & $10.5 \pm 0.42^{1}$ & $11.3 \pm 0.4^{\mathrm{c}}$ \\
\hline
\end{tabular}

-Values are statistically analyzed by one way ANOVA test followed by Tukey-Kramer posttest and reported as mean \pm SE.

-Number of animals in each group is 16.

${ }^{\mathrm{a}} \mathrm{P}<0.001$ vs $\mathrm{Cr}$ group $\&{ }^{\mathrm{F}} \mathrm{P}<0.01$ vs $\mathrm{Cr}$ group $\&{ }^{\mathrm{k}} \mathrm{P}<0.05$ vs $\mathrm{Cr}$ group

${ }^{\mathrm{b}} \mathrm{P}<0.001$ vs HFDS group $\&{ }^{\mathrm{g}} \mathrm{P}<0.01$ vs HFDS group.

${ }^{\mathrm{c}} \mathrm{P}<0.001$ vs probiotic group $\&{ }^{\mathrm{i}} \mathrm{P}<0.01$ vs probiotic group.

Results in (table 5) showed a significant increase in serum leptin concentration in HFDS, (HFDS with probiotic group) and (HFDS then probiotic group) in comparison to control group. Administration of probiotic alone (probiotic group) led to a significant decrease in serum leptin concentration in comparison to HFDS group. Results in the same table revealed that the serum TNF- $\boldsymbol{\alpha}$ concentration was significantly increased in HFDS group in comparison to control group, while administration of probiotic alone (probiotic group) led to a significant decrease in serum TNF- $\boldsymbol{\alpha}$ concentration in comparison to HFDS group.

Results in all tables showed that using of probiotic as prophylactic with HFDS from the beginning of the experiment (HFDS with probiotic group) improved the abdominal fat mass, serum lipid profile values, liver function enzymes, antioxidant parameters, serum leptin and serum TNF- $\boldsymbol{\alpha}$ levels much than using of it as treatment (HFDS then 
probiotic group), however there was no significant variation between (HFDS with probiotic group) and (HFDS then probiotic group).

\section{Discussion:-}

Palm oil is extensively used in restaurants, hotels and in preparation of varieties of food products (Basu et al., 2013; Gulati and Misra, 2017). In our study we induced obesity in male albino rats by adding $15 \%$ palm oil to normal diet and 20\% sucrose in drinking water. Palm oil is a high saturated oil (49 gm of saturated fatty acids/100gm of oil) (Basu et al., 2013; Gulati and Misra, 2017). Palmitic acid is the most saturated fatty acid in it (Edem, 2002; Gee Ping Tou, 2007; Sambanthamurthi et al., 2000; Mancini et al., 2015).

Some studies indicated that palm oil is healthy like olive oil due to its high content of oleic acid $48 \%$ (Sambanthamurthi et al., 2000; Mancini et al., 2015b) but others showed that palm oil is potentially unhealthy due to its high content of saturated palmitic acid (Bester et al., 2010; Mancini et al., 2015b; Odia et al., 2015).

Our results showed that consumption of $15 \%$ palm oil and $20 \%$ sucrose for 16 weeks lead to a significant increase in body weight and abdominal fat mass (table 1) which resulted from high caloric intake and increased lipogenesis also consumption of high fat diet and sucrose induced changes in the permeability of gut micro biota (reduce bacterial LPS removal) which caused endo-toxemia and metabolic dysfunctions (Harris et al., 2012; Etxeberria et al., 2015; Kirpich et al., 2015; Ojeda et al., 2016; Al-muzafar and Amin, 2017).

Probiotic administration (Lactobacillus paracasei) to germ-free mice led to an increase in the level of Angpt 14 which contribute to the decrease in fat mass in normal mice that are fed a high-fat diet supplemented with L. paracasei (Aronsson et al., 2010).

Probiotics have been shown to modify the production of satiety hormones when given to rats (Forssten et al., 2013).

Also there was a significant increase in serum triacylglycerol, cholesterol, LDL-C and VLDL-C concentrations (table 2) and supported by (Amin et al., 2011; Al-muzafar and Amin, 2017; An et al., 2011; Motshakeri et al., 2015). The effects of palm oil on blood lipids are as expected on the basis of its high saturated fat content which increase uptake of free fatty acid and lipogenesis (Al-muzafar and Amin, 2017), which supports the reduction in palm oil use by replacement with other vegetable oils low in saturated fatty acids (Sun et al., 2015).

Probiotics have physiologic functions that contribute to changes in the composition of gut microbiota, maintenance of a healthy body weight and control of factors associated with obesity through their effects on mechanisms controlling food intake, fat storage and alterations in gut microbiota (Sanchez et al., 2015).

The gut microbiota may participate in the regulation of fat storage, fat lipogenesis and fatty acid oxidation (Cani and Delzenne, 2009).

Probiotics have also been shown to interact with the resident bacterial members already present in the gut by altering their properties, which may also affect the metabolic pathways involved in the regulation of fat metabolism (Arora et al., 2013).

Recent studies by (Xiao et al., 2003), (Park et al., 2007) and (Psomas et al., 2003; Ryan et al., 2015) showed that probiotics, including Bifidobacterium longum, Lactobacillus acidophilus and Saccharomyces cerevisiae had hypocholesteremic effects in both rat and human. The mechanisms involved may be as follows: (1) fermentation products of lactic acid bacteria inhibit cholesterol synthesis enzymes and thus reduce cholesterol production; (2) the bacteria facilitate the elimination of cholesterol in feces; (3) the bacteria inhibit the absorption of cholesterol back into the body by binding with cholesterol; (4) the bacteria interfere with the recycling of bile salt (a metabolic product of cholesterol) and facilitate its elimination, which raises the demand for bile salt made from cholesterol and thus results in body cholesterol consumption (Beena and Prasad, 1997; Suzuki et al., 1991; Wu et al., 2015; Almuzafar and Amin, 2017) .

The increase in LDL-C concentration indicates consumption of a diet rich in saturated fatty acids that decrease the LDL receptor-mediator catabolism (Nicolosi et al., 1990; Spady et al., 1983). Besides, increased activity of lipoprotein lipase in hyperlipidemic animals leads to increased production of LDL-C from VLDL-C (Tebib et al., 1994). 
Oxidative stress is a state of imbalance between free radicals production and its degradation by antioxidant systems with increased accumulation of these radicals (Goh and Cooper, 2008; Kao et al., 2010).

In our result (table 4), palm oil \&sucrose uptake for 16 weeks lead to a significant decrease in liver homogenate concentration of both GSH and SOD, and a high significant increase in liver homogenate concentration of lipid peroxidation represented by MDA in comparison with that in control (cr group). These results are in agreement with (EL-Gohary and Hussien, 2015) whom explained the oxidative stress induced by obesity by different mechanisms, including the presence of excessive adipose tissue itself as adipocytes has been identified as a source of proinflammatory cytokines, including TNF- $\alpha$. These cytokines are potent stimulators for the production of reactive oxygen and nitrogen by macrophages and monocytes; therefore, a rise in the concentration of cytokines could be responsible for increased oxidative stress (Fonseca-Alaniz et al., 2007).

Obesity takes place in disorders that affect mitochondrial metabolism, which favors ROS generation and the development of oxidative stress. On the other hand, another mechanism has been proposed that involves an effect of high triglyceride (TG) on the functioning of the mitochondrial respiratory chain, in which intracellular TG, which is also high, inhibits translocation of adenine nucleotides and promotes the generation of superoxide (Monteiro and Azevedo, 2010).

Results in (table 4) indicated that probiotic may has antioxidant activity as it caused a modulatory effect on liver homogenate concentrations of GSH, SOD and MDA these results are in agreement with (Yadav et al., 2007, 2008).

In our study we observed a significant increase in ALT and AST activities (table 3). The increase in these two parameters indicates hepatotoxicity which is related to lipid induce-oxidative stress (Pepato et al., 2004; JuárezRojop et al., 2012), Lipids autoxidation generates radical oxygen species which attack cells and damage their functions (membrane fluidity and membrane bound enzyme) causing the leakage of these enzymes into the blood stream (Unger, 1995; Levy et al., 1999), This hypothesis is strengthened by a significant increase in MDA which is one of lipid peroxidation product.

Results in (table5) showed significance increase in liver homogenate TNF- $\alpha$ level in rat kept on HFD \&Sucrose for 16 weeks in comparison with that in control group (cr group), Our results agree with (Badkook, 2013; EL-Gohary and Hussien, 2015) as adipocytes has been identified as a source of proinflammatory cytokines, including TNF- $\alpha$. Administrations of probiotic showed a significant lower in the liver homogenate level of TNF- $\alpha$ (table5) as compared to HFD \&sucrose group. These results supported by (Wang et al., 2015) how reported that Bifidobacterium reduced hepatic TNF-a expression to the level measured in the control group.

Serum leptin level was significantly increased in our study (table5) as a result of (15\%) palm oil \& (20\%) sucrose consumption for 16 weeks, while probiotic administration ameliorated this change. Leptin is considered the major hormone in adipose tissues, and its high blood levels explain the extraordinary amount of fat deposition and probiotics facilitate the restoration of normal hormonal activity in adipose tissues (Considine et al., 1996; Hamilton et al., 1995 and Al-muzafar and Amin, 2017). Previous studies have shown similar results that decreased of fat mass resulted in a reduction in leptin concentrations (Kim et al., 2005; Azman et al., 2012).

Many hormones present in the body that regulate the level of leptin. As tumor necrosis factor- $\alpha$ (TNF- $\alpha$ ) serves as a paracrine regulator to increase the secretion of leptin, and fatty acids also influence leptin expression (Wasim, 2015; Fried et al., 2000).

\section{Conclusion:-}

Experimental induction of obesity by using of high fat diet (15\% palm oil) and sucrose (20\% in drinking water) for 16 weeks led to a significant increase in abdominal fat mass and body weight of rats. Serum levels of TC, TG, LDL$\mathrm{C}$ and VLDL-C were also significantly increased resulted in hypercholesterolemia and hypertriglyceridemia, while serum level of HDL-C was significantly decreased. HFDS has an oxidative stress effect represented by the significant increase in the liver homogenate level of MDA and the significant decrease in the level of both GSH and SOD of liver homogenate of rats. Also the serum level of the proinflammatory cytokines (TNF- $\alpha$ ) and leptin were significantly increased in HFDS group of rats. All the previous biochemical parameters in addition to body weight and abdominal fat mass were improved by administration of probiotic mixture either from the beginning of the 
experiment or started at the $8^{\text {th }}$ week of the experiment as probiotic mixture has an antioxidant, hypolipidemic and anti-obesity effects

\section{References:-}

1. Al-muzafar, H.M., and Amin, K.A. (2017): Probiotic mixture improves fatty liver disease by virtue of its action on lipid profiles, leptin, and inflammatory biomarkers. BMC Complement. Altern. Med. 17.

2. Amin, K.A., Kamel, H.H., and Abd Eltawab, M.A. (2011): Protective effect of Garcinia against renal oxidative stress and biomarkers induced by high fat and sucrose diet. Lipids Health Dis. 10, 6.

3. An, H.M., Park, S.Y., Lee, D.K., Kim, J.R., Cha, M.K., Lee, S.W., Lim, H.T., Kim, K.J., and Ha, N.J. (2011): Antiobesity and lipid-lowering effects of Bifidobacterium spp. in high fat diet-induced obese rats. Lipids Health Dis. $10,116$.

4. Aronsson, L., Huang, Y., Parini, P., Korach-André, M., Håkansson, J., Gustafsson, J.-Å., Pettersson, S., Arulampalam, V., and Rafter, J. (2010): Decreased Fat Storage by Lactobacillus Paracasei Is Associated with Increased Levels of Angiopoietin-Like 4 Protein (ANGPTL4). PLOS ONE 5, e13087.

5. Arora, T., Singh, S., and Sharma, R.K. (2013): Probiotics: Interaction with gut microbiome and antiobesity potential. Nutr. Burbank Los Angel. Cty. Calif 29, 591-596.

6. Austin, J., and Marks, D. (2009): Hormonal Regulators of Appetite. Int. J. Pediatr. Endocrinol. 2009.

7. Azman, K.F., Amom, Z., Azlan, A., Esa, N.M., Ali, R.M., Shah, Z.M., and Kadir, K.K.A. (2012): Antiobesity effect of Tamarindus indica L. pulp aqueous extract in high-fat diet-induced obese rats. J. Nat. Med. 66, 333342.

8. Badkook, M.M. (2013): Fermented Camel Milk Reduces Inflammation in Rats Fed a High-Fat Diet -. Int. J. Health Sci. Res. IJHSR 3, 7-17.

9. Basu, S., Babiarz, K.S., Ebrahim, S., Vellakkal, S., Stuckler, D., and Goldhaber-Fiebert, J.D. (2013): Palm oil taxes and cardiovascular disease mortality in India: economic-epidemiologic model. BMJ 347, f6048.

10. Beena, A., and Prasad, V. (1997): Effect of yogurt and bifidus yogurt fortified with skim milk powder, condensed whey and lactose-hydrolysed condensed whey on serum cholesterol and triacylglycerol levels in rats. J. Dairy Res. 64, 453-457.

11. Bester, D., Esterhuyse, A.J., Truter, E.J., and van Rooyen, J. (2010): Cardiovascular effects of edible oils: a comparison between four popular edible oils. Nutr. Res. Rev. 23, 334-348.

12. Beutler, E., Duron, O., and Kelly, B.M. (1963): Improved method for the determination of blood glutathione. J. Lab. Clin. Med. 61, 882-888.

13. Braud, L., Battault, S., Meyer, G., Nascimento, A., Gaillard, S., de Sousa, G., Rahmani, R., Riva, C., Armand, M., Maixent, J.-M., et al. (2017): Antioxidant properties of tea blunt ROS-dependent lipogenesis: beneficial effect on hepatic steatosis in a high fat-high sucrose diet NAFLD obese rat model. J. Nutr. Biochem. 40, 95104.

14. Bray, W.E. (1974): Clinical Laboratory Methods (Saint Louis: Mosby).

15. Burstein, M., Scholnick, H.R., and Morfin, R. (1970): Rapid method for the isolation of lipoproteins from human serum by precipitation with polyanions. J. Lipid Res. 11, 583-595.

16. Cani, P.D., and Delzenne, N.M. (2009): The role of the gut microbiota in energy metabolism and metabolic disease. Curr. Pharm. Des. 15, 1546-1558.

17. Considine, R.V., Sinha, M.K., Heiman, M.L., Kriauciunas, A., Stephens, T.W., Nyce, M.R., Ohannesian, J.P., Marco, C.C., McKee, L.J., and Bauer, T.L. (1996): Serum immunoreactive-leptin concentrations in normalweight and obese humans. N. Engl. J. Med. 334, 292-295.

18. Delzenne, N.M., Neyrinck, A.M., Bäckhed, F., and Cani, P.D. (2011): Targeting gut microbiota in obesity: effects of prebiotics and probiotics. Nat. Rev. Endocrinol. 7, 639-646.

19. Edem, D.O. (2002): Palm oil: biochemical, physiological, nutritional, hematological, and toxicological aspects: a review. Plant Foods Hum. Nutr. Dordr. Neth. 57, 319-341.

20. EL-Gohary, O.A., and Hussien, N.I. (2015): Effect of Exercise and Quercetin on Obesity Induced Metabolic and Renal Impairments in Albino Rats -. J. Physiol. Pharmacol. Adv. 5, 589-602.

21. Etxeberria, U., Arias, N., Boqué, N., Macarulla, M.T., Portillo, M.P., Martínez, J.A., and Milagro, F.I. (2015): Reshaping faecal gut microbiota composition by the intake of trans-resveratrol and quercetin in high-fat sucrose diet-fed rats. J. Nutr. Biochem. 26, 651-660.

22. Fonseca-Alaniz, M.H., Takada, J., Alonso-Vale, M.I.C., and Lima, F.B. (2007): Adipose tissue as an endocrine organ: from theory to practice. J. Pediatr. (Rio J.) 83, S192-203. 
23. Forssten, S.D., Korczyńska, M.Z., Zwijsen, R.M.L., Noordman, W.H., Madetoja, M., and Ouwehand, A.C. (2013): Changes in satiety hormone concentrations and feed intake in rats in response to lactic acid bacteria. Appetite 71, 16-21.

24. Fossati, P., and Prencipe, L. (1982): Serum triglycerides determined colorimetrically with an enzyme that produces hydrogen peroxide. Clin. Chem. 28, 2077-2080.

25. Fried, S.K., Ricci, M.R., Russell, C.D., and Laferrère, B. (2000): Regulation of leptin production in humans. J. Nutr. 130, 3127S-3131S.

26. Friedewald, W.T., Levy, R.I., and Fredrickson, D.S. (1972): Estimation of the concentration of low-density lipoprotein cholesterol in plasma, without use of the preparative ultracentrifuge. Clin. Chem. 18, 499-502.

27. Gee Ping Tou (2007): Analytical characteristics of crude and refined palm oil and fractions. Eur. J. Lipid Sci. Technol. 109, 373-379.

28. Goh, S.-Y., and Cooper, M.E. (2008): Clinical review: The role of advanced glycation end products in progression and complications of diabetes. J. Clin. Endocrinol. Metab. 93, 1143-1152.

29. Gulati, S., and Misra, A. (2017): Abdominal obesity and type 2 diabetes in Asian Indians: dietary strategies including edible oils, cooking practices and sugar intake. Eur. J. Clin. Nutr. 71, 850-857.

30. Hamilton, B.S., Paglia, D., Kwan, A.Y., and Deitel, M. (1995): Increased obese mRNA expression in omental fat cells from massively obese humans. Nat. Med. 1, 953-956.

31. Harris, K., Kassis, A., Major, G., and Chou, C.J. (2012): Is the gut microbiota a new factor contributing to obesity and its metabolic disorders? J. Obes. 2012, 879151.

32. Juárez-Rojop, I.E., Díaz-Zagoya, J.C., Ble-Castillo, J.L., Miranda-Osorio, P.H., Castell-Rodríguez, A.E., Tovilla-Zárate, C.A., Rodríguez-Hernández, A., Aguilar-Mariscal, H., Ramón-Frías, T., and Bermúdez-Ocaña, D.Y. (2012): Hypoglycemic effect of Carica papaya leaves in streptozotocin-induced diabetic rats. BMC Complement. Altern. Med. 12, 236.

33. Kao, M.P.C., Ang, D.S.C., Pall, A., and Struthers, A.D. (2010): Oxidative stress in renal dysfunction: mechanisms, clinical sequelae and therapeutic options. J. Hum. Hypertens. 24, 1-8.

34. Kim, J.H., Hahm, D.H., Yang, D.C., Kim, J.H., Lee, H.J., and Shim, I. (2005): Effect of crude saponin of Korean red ginseng on high-fat diet-induced obesity in the rat. J. Pharmacol. Sci. 97, 124-131.

35. Kirpich, I.A., Marsano, L.S., and McClain, C.J. (2015): Gut-liver axis, nutrition, and non-alcoholic fatty liver disease. Clin. Biochem. 48, 923-930.

36. Kjems, L.L., Røder, M.E., Dinesen, B., Hartling, S.G., Jørgensen, P.N., and Binder, C. (1993): Highly sensitive enzyme immunoassay of proinsulin immunoreactivity with use of two monoclonal antibodies. Clin. Chem. 39, 2146-2150.

37. Levy, Y., Zaltzberg, H., Ben-Amotz, A., Kanter, Y., and Aviram, M. (1999): $\beta$-Carotene affects antioxidant status in non-insulin-dependent diabetes mellitus. Pathophysiology 6, 157-161.

38. Maggi, S., Busetto, L., Noale, M., Limongi, F., and Crepaldi, G. (2015): Obesity: Definition and Epidemiology. ResearchGate 31-39.

39. Mancini, A., Imperlini, E., Nigro, E., Montagnese, C., Daniele, A., Orrù, S., and Buono, P. (2015): Biological and Nutritional Properties of Palm Oil and Palmitic Acid: Effects on Health. Mol. Basel Switz. 20, 1733917361.

40. Minami, J., Kondo, S., Yanagisawa, N., Odamaki, T., Xiao, J., Abe, F., Nakajima, S., Hamamoto, Y., Saitoh, S., and Shimoda, T. (2015): Oral administration of Bifidobacterium breve B-3 modifies metabolic functions in adults with obese tendencies in a randomised controlled trial. J. Nutr. Sci. 4.

41. Monteiro, R., and Azevedo, I. (2010): Chronic inflammation in obesity and the metabolic syndrome. Mediators Inflamm. 2010.

42. Motshakeri, M., Goh, Y.M., and Ebrahimi, M. (2015):Metabolic effects of high sucrose and saturated oil feeding on insulin resistance in Sprague-Dawley rats. Indian J. Exp. Biol. 53, 264-272.

43. Ngueguim, F.T., Esse, E.C., Dzeufiet, P.D.D., Gounoue, R.K., Bilanda, D.C., Kamtchouing, P., and Dimo, T. (2016): Oxidised palm oil and sucrose induced hyperglycemia in normal rats: effects of Sclerocarya birrea stem barks aqueous extract. BMC Complement. Altern. Med. 16, 47.

44. Nicolosi, R.J., Stucchi, A.F., Kowala, M.C., Hennessy, L.K., Hegsted, D.M., and Schaefer, E.J. (1990): Effect of dietary fat saturation and cholesterol on LDL composition and metabolism. In vivo studies of receptor and nonreceptor-mediated catabolism of LDL in cebus monkeys. Arterioscler. Dallas Tex 10, 119-128.

45. Odia, O.J., Ofori, S., and Maduka, O. (2015): Palm oil and the heart: A review. World J. Cardiol. 7, $144-149$.

46. Ojeda, P., Bobe, A., Dolan, K., Leone, V., and Martinez, K. (2016): Nutritional Modulation of Gut Microbiota The Impact on Metabolic Disease Pathophysiology. J. Nutr. Biochem. 28, 191-200. 
47. Park, D.-Y., Ahn, Y.-T., Park, S.-H., Huh, C.-S., Yoo, S.-R., Yu, R., Sung, M.-K., McGregor, R.A., and Choi, M.-S. (2013): Supplementation of Lactobacillus curvatus HY7601 and Lactobacillus plantarum KY1032 in dietinduced obese mice is associated with gut microbial changes and reduction in obesity. PloS One 8, e59470.

48. Park, Y.H., Kim, J.G., Shin, Y.W., Kim, S.H., and Whang, K.Y. (2007): Effect of dietary inclusion of Lactobacillus acidophilus ATCC 43121 on cholesterol metabolism in rats. J. Microbiol. Biotechnol. 17, 655662.

49. Pepato, M.T., Baviera, A.M., Vendramini, R.C., and Brunetti, I.L. (2004): Evaluation of toxicity after onemonths treatment with Bauhinia forficata decoction in streptozotocin-induced diabetic rats. BMC Complement. Altern. Med. 4, 7.

50. Psomas, E.I., Fletouris, D.J., Litopoulou-Tzanetaki, E., and Tzanetakis, N. (2003): Assimilation of cholesterol by yeast strains isolated from infant feces and Feta cheese. J. Dairy Sci. 86, 3416-3422.

51. Reitman, S., and Frankel, S. (1957): A colorimetric method for the determination of serum glutamic oxalacetic and glutamic pyruvic transaminases. Am. J. Clin. Pathol. 28, 56-63.

52. Richmond, W. (1973): Preparation and properties of a cholesterol oxidase from Nocardia sp. and its application to the enzymatic assay of total cholesterol in serum. Clin. Chem. 19, 1350-1356.

53. Ryan, J.J., Hanes, D.A., Schafer, M.B., Mikolai, J., and Zwickey, H. (2015): Effect of the Probiotic Saccharomyces boulardii on Cholesterol and Lipoprotein Particles in Hypercholesterolemic Adults: A SingleArm, Open-Label Pilot Study. J. Altern. Complement. Med. 21, 288-293.

54. Sabzghabaee, A.M., Kelishadi, R., Jelokhanian, H., Asgary, S., Ghannadi, A., and Badri, S. (2014): Clinical Effects of Portulaca Oleracea Seeds on Dyslipidemia in Obese Adolescents: a Triple-blinded Randomized Controlled Trial. Med. Arch. Sarajevo Bosnia Herzeg. 68, 195-199.

55. Sambanthamurthi, R., Sundram, K., and Tan, Y. (2000): Chemistry and biochemistry of palm oil. Prog. Lipid Res. 39, 507-558.

56. Sanchez, M., Panahi, S., and Tremblay, A. (2015): Childhood obesity: a role for gut microbiota? Int. J. Environ. Res. Public. Health 12, 162-175.

57. Satoh, K. (1978): Serum lipid peroxide in cerebrovascular disorders determined by a new colorimetric method. Clin. Chim. Acta Int. J. Clin. Chem. 90, 37-43.

58. Sikaris, K.A. (2004): The Clinical Biochemistry of Obesity. Clin. Biochem. Rev. 25, 165-181.

59. Spady, D.K., Bilheimer, D.W., and Dietschy, J.M. (1983): Rates of receptor-dependent and -independent low density lipoprotein uptake in the hamster. Proc. Natl. Acad. Sci. U. S. A. 80, 3499-3503.

60. Sun, Y., Neelakantan, N., Wu, Y., Lote-Oke, R., Pan, A., and van Dam, R.M. (2015): Palm Oil Consumption Increases LDL Cholesterol Compared with Vegetable Oils Low in Saturated Fat in a Meta-Analysis of Clinical Trials. J. Nutr. 145, 1549-1558.

61. Suzuki, Y. (Snow B.M.P.C.L., Kaizu, H., and Yamauchi, Y. (1991): Effect of cultured milk on serum cholesterol concentrations in rats fed high-cholesterol diets. Anim. Sci. Technol. Jpn.

62. Szasz, G. (1969): A kinetic photometric method for serum gamma-glutamyl transpeptidase. Clin. Chem. 15, $124-136$.

63. Tebib, K., Rouanet, J.M., and Besançon, P. (1994): Effect of grape seed tannins on the activity of some rat intestinal enzyme activities. Enzyme Protein 48, 51-60.

64. Unger, R.H. (1995): Lipotoxicity in the pathogenesis of obesity-dependent NIDDM. Genetic and clinical implications. Diabetes 44, 863-870.

65. Walter, A. (2009): A GLOBAL OVERVIEW OF VEGETABLE OILS, WITH REFERENCE TO BIODIESEL A Report for the IEA Bioenergy Task 40.

66. Wang, J., Tang, H., Zhang, C., Zhao, Y., Derrien, M., Rocher, E., van-Hylckama Vlieg, J.E.T., Strissel, K., Zhao, L., Obin, M., et al. (2015): Modulation of gut microbiota during probiotic-mediated attenuation of metabolic syndrome in high fat diet-fed mice. ISME J. 9, 1-15.

67. Wasim, M. (2015): Role of Leptin in Obesity. J. Obes. Weight Loss Ther. 05.

68. Wąsowski, M., Walicka, M., and Marcinowska-Suchowierska, E. (2013): Obesity - definition, epidemiology, pathogenesis. Postępy Nauk Med.

69. Wu, C.-C., Weng, W.-L., Lai, W.-L., Tsai, H.-P., Liu, W.-H., Lee, M.-H., and Tsai, Y.-C. (2015a): Effect of Lactobacillus plantarum Strain K21 on High-Fat Diet-Fed Obese Mice. Evid.-Based Complement. Altern. Med. ECAM 2015, 391767.

70. Wu, C.-C., Weng, W.-L., Lai, W.-L., Tsai, H.-P., Liu, W.-H., Lee, M.-H., and Tsai, Y.-C. (2015b): Effect of Lactobacillus plantarum Strain K21 on High-Fat Diet-Fed Obese Mice. Evid.-Based Complement. Altern. Med. ECAM 2015, 391767. 
71. Xiao, J.Z., Kondo, S., Takahashi, N., Miyaji, K., Oshida, K., Hiramatsu, A., Iwatsuki, K., Kokubo, S., and Hosono, A. (2003): Effects of milk products fermented by Bifidobacterium longum on blood lipids in rats and healthy adult male volunteers. J. Dairy Sci. 86, 2452-2461.

72. Yadav, H., Jain, S., and Sinha, P.R. (2007): Antidiabetic effect of probiotic dahi containing Lactobacillus acidophilus and Lactobacillus casei in high fructose fed rats. Nutr. Burbank Los Angel. Cty. Calif 23, 62-68.

73. Yadav, H., Jain, S., and Sinha, P.R. (2008): Oral administration of dahi containing probiotic Lactobacillus acidophilus and Lactobacillus casei delayed the progression of streptozotocin-induced diabetes in rats. J. Dairy Res. 75, 189-195.

74. Yoo, S.-R., Kim, Y.-J., Park, D.-Y., Jung, U.-J., Jeon, S.-M., Ahn, Y.-T., Huh, C.-S., McGregor, R., and Choi, M.S. (2013): Probiotics L. plantarum and L. curvatus in combination alter hepatic lipid metabolism and suppress diet-induced obesity. Obes. Silver Spring Md 21, 2571-2578.

75. Zhao, H., Lu, Z., Bie, X., and Lü, F. (2005): Analysis of positional distribution of fatty acids in triacylglycerols from lard by high performance liquid chromatography. Se Pu Chin. J. Chromatogr. 23, 142-145. 